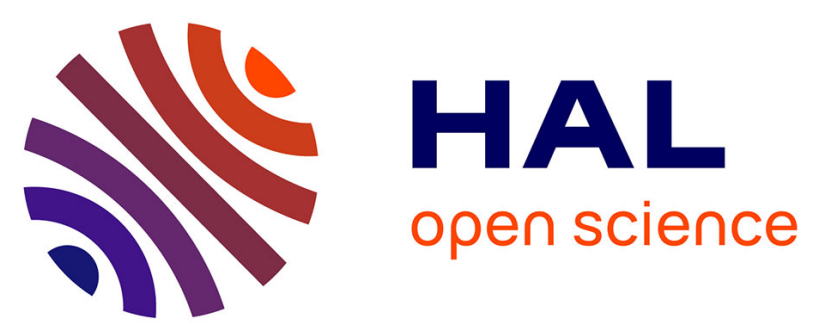

\title{
THE PREDICTIVE ABILITY OF RELATIVE EFFICIENCY FOR FUTURE EARNINGS:AN APPLICATION USING DATA ENVELOPMENT ANALYSIS TO SPANISH SMEs
}

Carmelo Reverte, Isidoro Guzman

\section{To cite this version:}

Carmelo Reverte, Isidoro Guzman. THE PREDICTIVE ABILITY OF RELATIVE EFFICIENCY FOR FUTURE EARNINGS:AN APPLICATION USING DATA ENVELOPMENT ANALYSIS TO SPANISH SMEs. Applied Economics, 2008, 42 (21), pp.2751-2757. 10.1080/00036840801964575 . hal-00582220

\section{HAL Id: hal-00582220 \\ https://hal.science/hal-00582220}

Submitted on 1 Apr 2011

HAL is a multi-disciplinary open access archive for the deposit and dissemination of scientific research documents, whether they are published or not. The documents may come from teaching and research institutions in France or abroad, or from public or private research centers.
L'archive ouverte pluridisciplinaire HAL, est destinée au dépôt et à la diffusion de documents scientifiques de niveau recherche, publiés ou non, émanant des établissements d'enseignement et de recherche français ou étrangers, des laboratoires publics ou privés. 


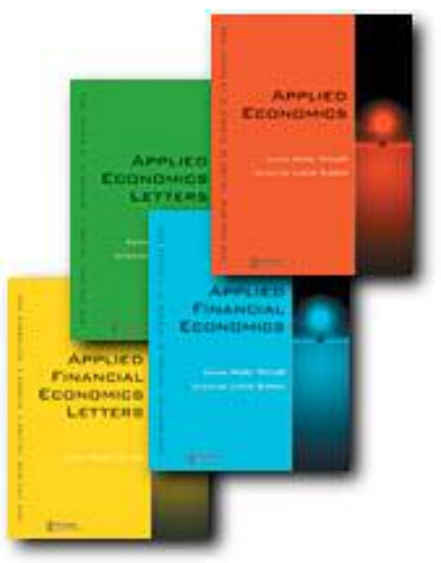

\section{THE PREDICTIVE ABILITY OF RELATIVE EFFICIENCY FOR FUTURE EARNINGS:AN APPLICATION USING DATA ENVELOPMENT ANALYSIS TO SPANISH SMES}

\begin{tabular}{|r|l|}
\hline Journal: & Applied Economics \\
\hline Manuscript ID: & APE-07-0063.R1 \\
\hline Journal Selection: & Applied Economics \\
\hline Date Submitted by the \\
Author: & 01 -Feb-2008 \\
\hline Complete List of Authors: & $\begin{array}{l}\text { REVERTE, CARMELO; Technical University of Cartagena, } \\
\text { Department of Accounting and Finance } \\
\text { GUZMAN, ISIDORO; Technical University of Cartagena, Department } \\
\text { of Accounting and Finance }\end{array}$ \\
\hline JEL Code: & $\begin{array}{l}\text { C14 - Semiparametric and Nonparametric Methods < C1 - } \\
\text { and Quantitative Methods, D24 - Production } \mid \text { Capital and Total } \\
\text { Factor Productivity ICapacity < D2 - Production and Organizations < } \\
\text { D - Microeconomics }\end{array}$ \\
\hline Keywords: & $\begin{array}{r}\text { relative efficiency, earnings prediction, DEA, SMEs } \\
\hline\end{array}$ \\
\hline
\end{tabular}

\section{S ScholarONE" \\ Manuscript Central}




\section{THE PREDICTIVE ABILITY OF RELATIVE EFFICIENCY FOR FUTURE EARNINGS: AN APPLICATION USING DATA ENVELOPMENT ANALYSIS TO SPANISH SMES}

\section{INTRODUCTION}

Research on the time-series properties of earnings has documented that the transitory component of current earnings makes this number, when used by itself, a noisy predictor of future earnings (e.g., Brooks and Buckmaster, 1976; Beaver and Morse, 1978). This transitory component of earnings is due to temporary economic shocks that do no persist over time. The implication of this finding is that a measure that better captures the underlying persistent component of earnings may prove very useful in predicting future earnings when used along with current earnings. As pointed out by Lee (1999: 418), "future empirical research needs to look beyond past earnings and book value, and seek to understand what other (preferably observable) financial and nonfinancial information might be useful in predicting future abnormal earnings (...) The aim is to understand what else, besides current earnings, might help us predict future earnings".

Our study, based on a large sample of 1939 Spanish small and medium enterprises (hereafter SMEs), is aimed at investigating whether an alternative measure of performance ignored in previous research on earnings forecasting -i.e., relative efficiency- is useful for predicting future earnings over and above current earnings and book value of equity. Relative efficiency captures the inherent ability of a firm -as compared to the other firms under analysis- to generate the maximum level of outputs given a certain level of inputs. In this paper we use a non-parametric technique based on linear programming referred to as Data Envelopment Analysis (DEA) in order to provide a numerical measure of the relative efficiency of business units in using available inputs to generate the maximum level of outputs. This technique has the advantage over other methodologies (such as the stochastic frontier analysis -SFA-) of avoiding the use of any a priori assumptions about the functional form of the production function.

Our findings highlight that our efficiency measure has an incremental predictive ability over and above current earnings and book value of equity for predicting future earnings. Moreover, we have further validated the models in a holdout sample and our results evidence the highest forecast accuracy of the model that includes our DEA-based efficiency measure as an additional predictor to current earnings and book value of equity.

The rest of the paper is structured as follows. In the next section we discuss the DEA methodology used in our empirical analysis to measure relative efficiency. In Section 3 we present the research design, including the methodology, variables, hypotheses and a description of the 
sample. In section 4 we present the results from the empirical analysis. Finally, we summarise the main conclusions of our study.

\section{EFFICIENCY MEASURE: DATA ENVELOPMENT ANALYSIS}

Data Envelopment Analysis (DEA) is a non-parametric technique developed by Charnes et al. (1978) that using linear programming determines the relative efficiency of decision making units (DMUs) in the use of single or multiple inputs for the production of single or multiple outputs ${ }^{1}$. The advantage of this technique is that there is no need to make any a priori assumptions about the functional form of the production function. Instead, an empirical production function, in the form of a piece-wise linear frontier, is fitted to the observed data based on the amounts of outputs and inputs of the business units under analysis so that the relative efficiency is assessed against the benchmark of the so-called "best-practice frontier". Those DMUs placed on the frontier are deemed to be efficient while those DMUs situated below the frontier are regarded as inefficient ${ }^{2}$.

Assuming that there are $n$ DMUs that use a vector of $m$ inputs to produce a vector of $s$ outputs, DEA allows to determine the efficiency $\left(h_{z}\right)$ of each DMU $\left(\mathrm{DMU}_{\mathrm{z}}\right)$ by solving the following linear programming problem:

$$
\operatorname{Max} h_{z}=\frac{\sum_{s} u_{r} y_{r z}}{\sum_{i} v_{i} x_{i z}}
$$

subject to:

$$
\begin{aligned}
& h_{z}=\frac{\sum_{s} u_{r} y_{r f}}{\sum_{i} v_{i} x_{i f}} \leq 1 \quad \mathrm{f}=1,2, \ldots \ldots, \mathrm{n} \\
& u_{r} \geq 0, \mathrm{r}=1, \ldots, \mathrm{s} \\
& v_{i} \geq 0, \mathrm{i}=1, \ldots, \mathrm{m}
\end{aligned}
$$

where $y_{r}$ and $x_{i}$ represent the amount of output $r$ and input $i$, respectively while $u_{r}$ and $v_{i}$ represent their corresponding weights.

The previous formulation corresponds to the original model developed by Charnes et al. (1978), known as the CCR model, which assumes that all DMUs operate under constant returns to scale. This assumption was relaxed in the model proposed by Banker et al. (1984) -known as the

\footnotetext{
${ }^{1}$ The DEA model can have two different orientations: a) an output orientation, in which the maximum amount of outputs for a given level of inputs is pursued; b) an input orientation, in which it is pursued to consume the minimum amount of inputs to achieve a given level of outputs.

${ }^{2}$ For a review of the DEA approach and its methodological problems, see for instance Färe and Zelenyuk (2002), Sengupta (2002), Färe et al. (2004) and Barnum and Gleason (2005, 2006).
} 
BCC model- that allows for variable returns to scale. Banker (1993) proved that in large samples the BCC estimator is consistent because the distance between the DEA estimate and the true efficiency score goes towards zero.

The output-oriented BCC model (Banker et al., 1984) to estimate the efficiency of each DMU is given by solving the following linear programming:

$\operatorname{Max} \theta_{z}$

$$
\begin{array}{ll}
\sum_{f=1}^{\text {s.a.: }} \lambda_{f} x_{i f}+S^{i}=x_{i z} & \mathrm{i}=1, \ldots, \mathrm{m} \\
\theta_{z} y_{r z}-\sum_{f=1}^{n} \lambda_{f} y_{r f}+S^{o}=0 & \mathrm{r}=1, \ldots, \mathrm{s} \\
\sum_{f=1}^{n} \lambda_{f}=1 & \\
\theta_{z} \geq 0 ; \lambda_{f} \geq 0 & \mathrm{f}=1, \ldots, \mathrm{n}
\end{array}
$$

where $\theta_{z}$ is the efficiency score for the DMU $z$ being evaluated, $\mathrm{x}_{\mathrm{if}}$ is the amount of input $i$ consumed by DMU $f, \mathrm{y}_{\mathrm{rf}}$ is the amount of output $r$ produced by $\operatorname{DMU} f, \mathrm{x}_{\mathrm{iz}}$ is the amount of input $i$ consumed by the DMU $z$ being evaluated, $\mathrm{y}_{\mathrm{rz}}$ is the amount of output $r$ produced by the DMU $z$ being evaluated, $\lambda_{\mathrm{f}}$ is the weight on the inputs/outputs of DMU $f$ and $\mathrm{S}^{\mathrm{o}}$ and $\mathrm{S}^{\mathrm{i}}$ are the slacks of the linear programming model.

The optimal value $\left(\theta_{z}\right)$ of the linear program ranges between 1 and $\infty$, such that it is equal to 1 for efficient units and higher than 1 for inefficient units. The estimated relative efficiency measure $\left(\varphi_{z}=1 / \theta_{z}\right)$ varies between 0 and 1 . Therefore, a DMU with a relative efficiency measure $\left(\varphi_{z}\right)$ equal to 1 is regarded as efficient whereas if it takes a value of, for example, 0.85 this would imply that the DMU being evaluated will have to increase its output an $15 \%$ of the estimated value in the efficient frontier.

\section{RESEARCH DESIGN}

\subsection{Methodology, variables and hypothesis}

As efficiency is sector-sensitive, we have splitted our sample of SMEs in several sectors and computed the efficiency of each firm in comparison with the rest of firms in the same sector. After analysing the data, firms were grouped in the following three sectors: a) Manufacturing; b) Service sector and c) Construction. 
The methodology used in our empirical study is based on three stages. In the first one, we obtain for each year and firm the DEA-based efficiency scores. As in Abad et al. (2006), the proposed DEA model takes the inputs and outputs that correspond with those of a typical production function (see Table 1).

\begin{tabular}{ll}
\hline \multicolumn{1}{c}{ Table 1. DEA model (output orientation) } \\
\hline $\begin{array}{l}\text { Output: } \\
\text { - Revenues } \\
\text { Inputs: } \\
\text { - Cost of Materials consumed } \\
\text { - Personnel expenses } \\
\text { - Depreciation expense } \\
\text { - Other operating expense }\end{array}$ \\
\end{tabular}

Regarding the DEA methodology, we have computed the efficiency scores based on Banker et al. (1984) that consider variable returns to scale (BCC model). Moreover, we have chosen an output orientation as we are interested in relating our efficiency measure to future earnings. Therefore, our model will be oriented towards achieving the maximum level of revenues for a given level of inputs.

In the second stage, we estimate the following regression models (see Table 2) in order to test the incremental predictive ability of our relative efficiency measure over and above current earnings and book value of equity.

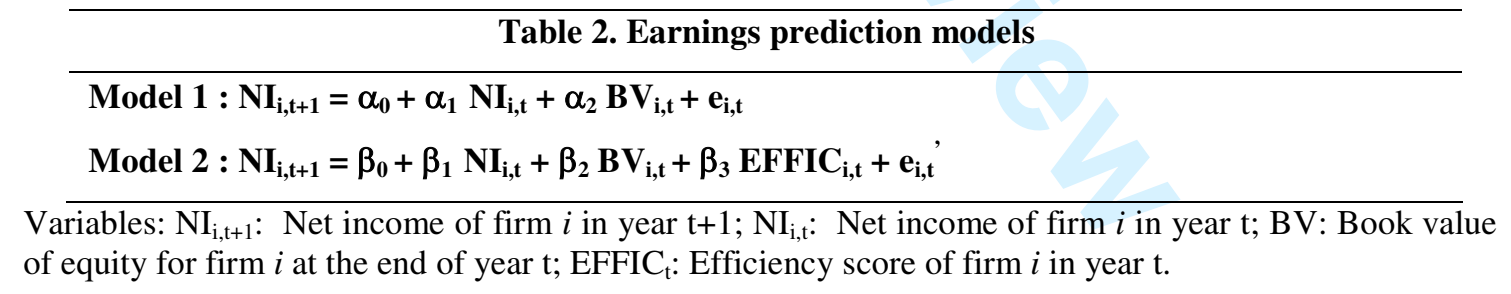

The first model includes current earnings and book value of equity as regressors. Regarding the former, there is a huge number of studies that have shown the predictive ability of current earnings for predicting future earnings (e.g., Ball and Watts, 1972; Albretch et al., 1977; Watts and Leftwich, 1977). Concerning book value of equity, the Ohlson valuation model (1995) shows its usefulness for predictive purposes, being that higher the lower the persistence of current earnings. In this respect, Shroff (1999) -for the US- and Reverte (2003) -for Spain- have corroborated the predictive ability of book value of equity for the case of listed firms. The second model includes our relative efficiency measure as an additional regressor in order to test the following hypothesis: The 
DEA efficiency measure in year $t$ is positively associated with next year's $(t+1)$ earnings, after controlling for the effect of current earnings and book value of equity. To the extent our efficiency measure captures the permanent component of earnings, it should be able to predict future earnings over and above current earnings and book value. Therefore, we expect $\beta_{3}$ to be positive and statistically significant.

Finally, in the last stage of our study, we validate our models in a holdout sample different to that used in their estimation by computing the differences in earnings forecasted by models (1) and (2) and actual earnings corresponding to our sample of firms for year 2004. In order to assess the forecast accuracy of both models, we compute the mean absolute percentage error, whose formulation is shown on Table 3. This measure has two advantages. First, as forecast errors are taken in absolute value, it avoids negative and positive errors to compensate each other. Second, it is not sensitive to scale as errors are divided by the actual value of the forecasted variable.

\begin{tabular}{l}
\hline Table 3. Forecast accuracy measure \\
\hline Mean absolute percentage error $=\frac{1}{N} \sum\left|\frac{e_{i}}{y_{i}}\right|$ \\
\hline Notes: \\
$\mathrm{e}_{\mathrm{i}}:$ forecast error (difference between the actual and forecasted value). \\
$\mathrm{y}_{\mathrm{i}}:$ actual value of forecasted variable. \\
$\mathrm{N}:$ number of observations in the forecast period.
\end{tabular}

Once we have computed the mean absolute percentage error, we examine whether the differences in the forecast errors derived from models (1) and (2) are statistically significant by applying the non-parametric Wilcoxon signed-rank test, which is appropiate when the distribution of the errors departs from normality.

\subsection{Sample}

Data used in our study are obtained from the database SABI. We have chosen small and medium-sized firms (SMEs) with the legal form of public or limited liability companies ${ }^{3}$. The sample period ranges from 1999 to 2003 , including additionally the year 2004 in order to validate our models. To ensure reliability of our data, we include only SMEs with a favourable audit report. As a result of the previous filters, our sample comprises 1939 SMEs and a total of 7756 firm/year observations for our four-year estimation period. The composition of the sample by sector is as follows: a) Manufacturing sector (802 firms/3208 observations), b) service sector (957 firms /3828

\footnotetext{
${ }^{3}$ In order to define a firm as SME, we have followed the Recommendation 2003/361/EC of the European Commission on SME definition issued on $6^{\text {th }}$ May 2003, selecting the maximum levels proposed in this Recommendation, namely: total assets, up to 43 million euros; sales revenues, up to 50 million euros, and average number of employees, up to 250.
} 
observations) and c) construction sector (180 firms/720 observations). Table 4 reports the descriptive statistics of our regressors (i.e., earnings, book value of equity and efficiency) for each of the three sectors and also for the aggregate sample. As it can be observed, the mean efficiency scores are quite similar across sectors, ranging from $81.7 \%$ for the manufacturing sector to $85.4 \%$ for the service sector. The mean efficiency value for the pooled sample is $83.6 \%$.

\begin{tabular}{|c|c|c|c|}
\hline \multicolumn{4}{|c|}{ Table 4. Descriptive Statistics by Sectors and for the Aggregate Sample } \\
\hline \multicolumn{4}{|c|}{ Panel A: Manufacturing sector $(\mathrm{N}=3208$ obs. $)$} \\
\hline & $\mathbf{N I}_{\mathrm{t}}$ & $\mathbf{B V}_{\mathrm{t}}$ & EFFIC $_{t}$ \\
\hline Mean & 611.22 & 5018.69 & 0.817 \\
\hline Median & 374.00 & 3680.00 & 0.810 \\
\hline Standard deviation & 838.69 & 4475.07 & 0.099 \\
\hline Minimum & -4650.00 & -2654.00 & 0.082 \\
\hline Maximum & 10440.00 & 33853.00 & 1.000 \\
\hline \multicolumn{4}{|c|}{ Panel B: Service Sector $(\mathrm{N}=3828$ obs. $)$} \\
\hline & $\mathrm{NI}_{\mathrm{t}}$ & $\mathbf{B V}_{\mathrm{t}}$ & EFFIC $_{t}$ \\
\hline Mean & 453.69 & 3493.08 & 0.854 \\
\hline Median & 277.00 & 2360.05 & 0.856 \\
\hline Standard deviation & 680.56 & 3603.72 & 0.088 \\
\hline Minimum & -4201.00 & -1459.00 & 0.171 \\
\hline Maximum & 7379.00 & 31869.00 & 1.000 \\
\hline \multicolumn{4}{|c|}{ Panel C: Construction sector (N=720 obs.) } \\
\hline & $\mathrm{NI}_{\mathrm{t}}$ & $\mathbf{B V}_{\mathrm{t}}$ & EFFIC $_{t}$ \\
\hline Mean & 502.80 & 3019.87 & 0.828 \\
\hline Median & 328.00 & 2246.00 & 0.826 \\
\hline Standard deviation & 696.75 & 2835.88 & 0.121 \\
\hline Minimum & -4048.00 & -733.00 & 0.088 \\
\hline Maximum & 5857.00 & 19916.00 & 1.000 \\
\hline \multicolumn{4}{|c|}{ Panel D: Aggregate sample (N=7756 obs.) } \\
\hline & $\mathbf{N I}_{\mathbf{t}}$ & $\mathbf{B V}_{\mathrm{t}}$ & EFFIC $_{t}$ \\
\hline Mean & 523.42 & 4080.29 & 0.836 \\
\hline Median & 316.00 & 2785.00 & 0.835 \\
\hline Standard deviation & 755.05 & 4009.44 & 0.097 \\
\hline Minimum & -4650.00 & -2654.00 & 0.082 \\
\hline Maximum & 10440.00 & 33853.00 & 1.000 \\
\hline
\end{tabular}

Table 5. Correlations among explanatory variables Panel A: Manufacturing sector $(\mathrm{N}=3208$ obs. $)$

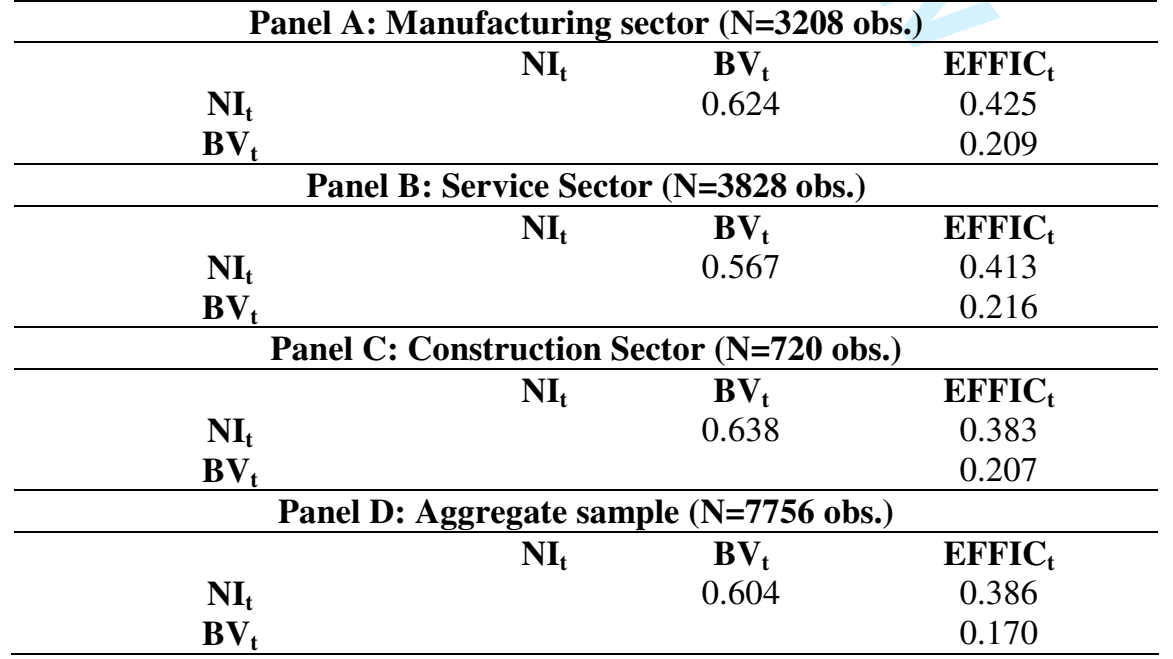

Notes: $\mathrm{NI}_{\mathrm{t}}$ : Net income of firm $i$ in year $\mathrm{t}$ (thousands of euros); BV: Book value of equity for firm $i$ at the end of year $\mathrm{t}$ (thousands of euros); EFFIC $\mathrm{t}_{\mathrm{t}}$ : Efficiency score of firm $i$ in year $\mathrm{t}$. 
Table 5 shows the correlation matrix among the regressors. It can be observed that our efficiency measure is not highly correlated with both current earnings and book value of equity in the three sectors. Specifically, for the pooled sample, that correlations are 0.39 and 0.17 , respectively. Hence, we can assert that the information captured by our efficiency measure is not already contained in both current earnings and book value of equity, avoiding any collinearity problem.

\section{RESULTS}

\subsection{Cluster analysis}

In order to get a first approximation of descriptive nature on the relationship between our efficiency measure and future earnings for our sample of Spanish SMEs, we have performed a $k$ means cluster analysis. Specifically, for each of the three sectors and for the pooled sample, we have identified three clusters based on the current value of the efficiency measure $\left(\mathrm{EFFIC}_{\mathrm{t}}\right)$. Then, we compute for each cluster the mean value of next-year's earnings $\left(\mathrm{NI}_{\mathrm{t}+1}\right)$ and, finally, we perform the Kruskal-Wallis test in order to examine whether the differences in the mean value of next-year's earnings across the three clusters are statistically significant. Results from this cluster analysis are reported on Table 6.

\begin{tabular}{cccc}
\hline \multicolumn{4}{c}{ Table 6. Cluster Analysis } \\
\hline \multicolumn{4}{c}{ Panel A: Manufacturing Sector $(\mathbf{N}=\mathbf{3 2 0 8}$ obs. $)$} \\
\hline Cluster & $\mathbf{N}$ & EFFIC $_{\mathbf{t}}$ & $\mathbf{N I}_{\mathbf{t}+\mathbf{1}}$ \\
\hline 1 & 1045 & 0.711 & 266.12 \\
2 & 1448 & 0.824 & 549.21 \\
3 & 715 & 0.955 & 1218.17
\end{tabular}

Kruskal-Wallis test for $\mathrm{NI}_{\mathrm{t}+1}: \chi^{2}=460.03$ ( $p$-value: 0.0001$)$

\begin{tabular}{cccc}
\hline \multicolumn{4}{c}{ Panel B: Service Sector $(\mathbf{N}=3828$ obs. $)$} \\
\hline Cluster & $\mathbf{N}$ & EFFIC $_{\mathbf{t}}$ & $\mathbf{N I}_{\mathbf{t + 1}}$ \\
\hline 1 & 845 & 0.737 & 208.19 \\
2 & 1819 & 0.845 & 370.76 \\
3 & 1164 & 0.952 & 810.86
\end{tabular}

Kruskal-Wallis test for $\mathrm{NI}_{\mathrm{t}+1}: \chi^{2}=452.56$ ( $p$-value: 0.0001$)$

\begin{tabular}{cccc}
\hline \multicolumn{4}{c}{ Panel C: Construction Sector $(\mathbf{N}=\mathbf{7 2 0}$ obs.) } \\
\hline Cluster & $\mathbf{N}$ & EFFIC $_{\mathbf{t}}$ & $\mathbf{N I}_{\mathbf{t + 1}}$ \\
\hline 1 & 229 & 0.694 & 333.26 \\
2 & 278 & 0.826 & 550.34 \\
3 & 213 & 0.975 & 938.12
\end{tabular}

Kruskal-Wallis test for $\mathrm{NI}_{\mathrm{t}+1}: \chi^{2}=49.12(p$-value: 0.0001$)$

\begin{tabular}{cccc}
\hline \multicolumn{4}{c}{ Panel D: Aggregate sample $(\mathbf{N}=\mathbf{7 7 5 6}$ obs. $)$} \\
\hline Cluster & $\mathbf{N}$ & EFFIC $_{\mathbf{t}}$ & $\mathbf{N I}_{\mathbf{t + 1}}$ \\
\hline 1 & 2096 & 0.718 & 261.17 \\
2 & 3559 & 0.835 & 454.68 \\
3 & 2101 & 0.956 & 949.51
\end{tabular}

Kruskal-Wallis test for $\mathrm{NI}_{t+1}: \chi^{2}=798.55$ ( $p$-value: 0.0001 )

Notes: $\mathrm{N}$ : Number of observations in each cluster; $\mathrm{NI}_{\mathrm{t}+1}=$ Net income in $\mathrm{t}+1$ (thousands of euros); EFFIC $\mathrm{t}$ : Efficiency score in year t. 
As can be shown on Table 6, in the three sectors the higher the value of efficiency in the current period the higher the value of next-year's earnings. For cluster 1, comprised by those observations with the lowest values of the efficiency measure ( 0.718 for the aggregate sample), the mean value of next-year's earnings is 261.17 millions euros. On the contrary, in cluster 3, comprised by those observations with the highest values of the efficiency measure ( 0.956 for the aggregate sample), the mean value of next-year's earnings is 949.51 millions euros. The KruskalWallis test evidences that the differences in the mean value of next-year's earnings across the three clusters are statistically significant at the $1 \%$ level for the three sectors and also for the aggregate sample.

\subsection{Estimation results}

Table 7 reports the results for the pooled sample period (1999-2003) regarding the estimation of the two earnings prediction models (1) and (2) for the three sectors and for the aggregate sample.

\section{Table 7. Estimation results of models (1) and (2)}

\begin{tabular}{|c|c|c|c|c|c|c|}
\hline \multicolumn{7}{|c|}{$\begin{array}{l}\text { Model 1: } \mathbf{N I}_{\mathrm{i}, t+1}=\alpha_{0}+\alpha_{1} \mathbf{N I}_{\mathrm{i}, \mathrm{t}}+\alpha_{2} \mathbf{B V}_{\mathrm{i}, \mathrm{t}}+\mathbf{e}_{\mathrm{i}, \mathrm{t}} \\
\text { Model 2: } \mathrm{NI}_{\mathrm{i}, \mathrm{t}+1}=\beta_{0}+\beta_{1} \mathbf{N I}_{\mathrm{i}, \mathrm{t}}+\beta_{2} \mathbf{B V}_{\mathrm{i}, \mathrm{t}}+\beta_{3} \text { EFFIC }_{\mathrm{i}, \mathrm{t}}+\mathbf{e}_{\mathrm{i}, \mathrm{t}}\end{array}$} \\
\hline \multicolumn{7}{|c|}{ Panel A: Manufacturing sector ( $\mathrm{N}=3208$ obs.) } \\
\hline Model & Intercept & $\mathbf{N I}_{\mathrm{t}}$ & BVt & EFFIC $_{t}$ & $\begin{array}{l}\text { F-Test } \\
\left(\beta_{3}=0\right)\end{array}$ & Adj. $R^{2}$ \\
\hline Model 1 & $\begin{array}{l}56.93^{*} \\
(3.45)\end{array}$ & $\begin{array}{c}0.82 * \\
(17.87)\end{array}$ & $\begin{array}{l}0.01 \\
(1.60)\end{array}$ & & & 0.640 \\
\hline Model 2 & $\begin{array}{c}-387.84^{*} \\
(-3.28)\end{array}$ & $\begin{array}{c}0.79^{*} \\
(15.89)\end{array}$ & $\begin{array}{l}0.01 * * * \\
(1.80)\end{array}$ & $\begin{array}{l}561.52 * \\
(3.65)\end{array}$ & $\begin{array}{c}13.32 \\
(p \text {-value }=0.000)\end{array}$ & 0.644 \\
\hline \multicolumn{7}{|c|}{ Panel B: Service Sector (N=3828 obs.) } \\
\hline & Intercept & $\mathbf{N I}_{\mathbf{t}}$ & BVt & EFFIC $_{t}$ & $\begin{array}{l}\text { F-Test } \\
\left(\beta_{3}=0\right)\end{array}$ & Adj. $\mathbf{R}^{2}$ \\
\hline Model 1 & $\begin{array}{r}53.70^{*} \\
(4.31)\end{array}$ & $\begin{array}{l}0.76^{*} \\
(15.50)\end{array}$ & $\begin{array}{l}0.02 * \\
(3.32)\end{array}$ & & & 0.603 \\
\hline Model 2 & $\begin{array}{c}-284.91^{*} \\
(-2.20)\end{array}$ & $\begin{array}{c}0.74^{*} \\
(13.56)\end{array}$ & $\begin{array}{l}0.01^{*} \\
(3.37)\end{array}$ & $\begin{array}{c}407.28^{*} \\
(2.57)\end{array}$ & $\begin{array}{c}6.58 \\
(p \text {-value }=0.010)\end{array}$ & 0.605 \\
\hline \multicolumn{7}{|c|}{ Panel C: Construction sector ( $\mathrm{N}=\mathbf{7 2 0}$ obs.) } \\
\hline & Intercept & $\mathbf{N I}_{\mathbf{t}}$ & BVt & EFFIC $_{t}$ & $\begin{array}{l}\text { F-Test } \\
\left(\beta_{3}=0\right)\end{array}$ & Adj. $R^{2}$ \\
\hline Model 1 & $\begin{array}{l}67.33 \\
(1.21)\end{array}$ & $\begin{array}{l}0.47^{*} \\
(4.27)\end{array}$ & $\begin{array}{l}0.10^{*} \\
(3.89)\end{array}$ & & & 0.424 \\
\hline Model 2 & $\begin{array}{c}-338.94 * * * \\
(-1.65)\end{array}$ & $\begin{array}{l}0.43^{*} \\
(3.75)\end{array}$ & $\begin{array}{l}0.10^{*} \\
(3.97)\end{array}$ & $\begin{array}{c}508.68 * * * \\
(1.89)\end{array}$ & $\begin{array}{c}3.57 \\
(p \text {-value }=0.059)\end{array}$ & 0.428 \\
\hline \multicolumn{7}{|c|}{ Panel D: Aggregate sample (N=7756 obs.) } \\
\hline & Intercept & $\mathrm{NI}_{\mathrm{t}}$ & BVt & EFFIC $_{t}$ & $\begin{array}{l}\text { F-Test } \\
\left(\beta_{3}=0\right)\end{array}$ & Adj. $R^{2}$ \\
\hline Model 1 & $\begin{array}{c}61.77^{*} \\
(6.23)\end{array}$ & $\begin{array}{c}0.78^{*} \\
(23.93)\end{array}$ & $\begin{array}{l}0.02^{*} \\
(4.20)\end{array}$ & & & 0.600 \\
\hline Model 2 & $\begin{array}{c}-307.12 * \\
(-3.92)\end{array}$ & $\begin{array}{c}0.75^{*} \\
(21.37)\end{array}$ & $\begin{array}{l}0.02^{*} \\
(4.42)\end{array}$ & $\begin{array}{c}452.16^{*} \\
(4.60)\end{array}$ & $\begin{array}{c}21.16 \\
(p \text {-value }=0.000)\end{array}$ & 0.603 \\
\hline
\end{tabular}

Notes: White-adjusted $t$-statistics are reported in parentheses. *,**, *** indicate significance at $1 \%, 5 \%$ and $10 \%$, respectively. The $F$-value tests the hypothesis that the coefficient on EFFIC is zero in model (2). 
It can be observed that, as hypothesised, our efficiency measure is positively and significantly associated with next-year's earnings. The $F$-test indicates that efficiency has an incremental explanatory power over and above current earnings and book value of equity for predicting next-year's earnings in the three sectors (manufacturing, services and construction). For the pooled sample, the $F$-test is statistically significant at the $1 \%$ level ( $p$-value $=0.00$ ). This finding corroborates our main hypothesis, i.e., the more efficient firms in the use of available resources -as compared to the rest of firms in the sample- have higher earnings in the following period than less efficient firms.

\subsection{Validation results}

In the predictive ability studies the relevant test is the validation of the models in a holdout sample different to that used in their estimation. In this respect, our hypothesis is as follows: The model including our efficiency measure (model 2) predicts more accurately next-year's earnings than the model that only includes current earnings and book value of equity (model 1).

We first compute the differences in earnings forecasted by models (1) and (2) and actual earnings corresponding to our sample of firms for year 2004. In order to assess the forecast accuracy of both models, we compute the mean absolute percentage error.

\begin{tabular}{ccc}
\hline \multicolumn{3}{c}{ Table 8. Validation of the models } \\
\hline \multicolumn{3}{c}{ Panel A: Manufacturing Sector } \\
\hline & Model 1 & Model 2 \\
\hline Mean absolute percentage error & 2.87 & 2.63
\end{tabular}

Wilcoxon test: $\mathrm{Z}=-3.02$ ( $p$-value: 0.0025 )

\begin{tabular}{ccc}
\hline \multicolumn{3}{c}{ Panel B: Service Sector } \\
\hline & Model 1 & Model 2 \\
\hline Mean absolute percentage error & 1.41 & 1.31
\end{tabular}

Wilcoxon test: $\mathrm{Z}=-3.62$ ( $p$-value: 0.0003$)$

\begin{tabular}{ccc}
\hline \multicolumn{4}{c}{ Panel C: Construction Sector } \\
\hline & Model 1 & Model 2 \\
\hline Mean absolute percentage error & 1.53 & 1.38
\end{tabular}

Wilcoxon test: $\mathrm{Z}=-1.71$ ( $p$-value: 0.0873$)$

\begin{tabular}{ccc}
\hline \multicolumn{3}{c}{ Panel D: Aggregate Sample } \\
\hline & Model 1 & Model 2 \\
\hline Mean absolute percentage error & 2.18 & 2.10
\end{tabular}

Wilcoxon test: $\mathrm{Z}=-3.87$ ( $p$-value: 0.0001$)$

Notes: Mean absolute percentage error (defined in Table 3)

Model $1: \mathrm{NI}_{\mathrm{i}, \mathrm{t}+1}=\alpha_{0}+\alpha_{1} \mathrm{NI}_{\mathrm{i}, \mathrm{t}}+\alpha_{2} \mathrm{BV}_{\mathrm{i}, \mathrm{t}}+\mathrm{e}_{\mathrm{i}, \mathrm{t}}$

Model $2: \mathrm{NI}_{\mathrm{i}, \mathrm{t}+1}=\beta_{0}+\beta_{1} \mathrm{NI}_{\mathrm{i}, \mathrm{t}}+\beta_{2} \mathrm{BV}_{\mathrm{i}, \mathrm{t}}+\beta_{3} \mathrm{EFFIC}_{\mathrm{i}, \mathrm{t}}+\mathrm{e}_{\mathrm{i}, \mathrm{t}}$ 
Table 8 reports, for the three sectors and the pooled sample, the validation results as well as the Wilcoxon signed-rank test in order to examine whether the differences in the forecast errors derived from models (1) and (2) are statistically significant. Our results document that the model including the efficiency measure (model 2) has the highest forecast accuracy for the three sectors since the forecast errors are lower than model 1 . Moreover, the $Z$-statistic of the Wilcoxon test indicates that the differences between the forecast errors of both models are statistically significant ( $p$-value $=0.0001$ for the pooled sample) .

\section{CONCLUDING REMARKS}

Research on earnings prediction has documented that the transitory component of current earnings makes that figure less useful for predicting future earnings (e.g., Brooks and Buckmaster, 1976; Beaver and Morse, 1978). The implication of this finding is that a measure that better captures the underlying persistent component of earnings might prove very useful in predicting future earnings when used along with current earnings. Our study, based on a large sample of 1939 Spanish SMEs, investigates whether an alternative mesure of performance ignored in previous research on earnings forecasting -i.e, relative efficiency- has predictive ability over and above current earnings and book value for predicting future earnings. Relative efficiency captures the inherent ability of a firm to make the most productive use of available resoureces as compared to the rest of firms in the sample. In order to measure the relative efficiency of our sample firms we use the Data Envelopment Analysis (DEA) non-parametric technique.

Our findings highlight that our efficiency measure has an incremental predictive ability over and above current earnings and book value of equity for predicting future earnings in the three sectors considered (manufacturing, services and construction). Moreover, we have further validated the models in a holdout sample and our results evidence again in the three sectors the highest forecast accuracy of the model that includes our efficiency measure as an additional predictor to current earnings and book value of equity. Therefore, our research suggest the usefulness of relative efficiency to capture the persistent component of earnings and, as a result, support its inclusion as an additional predictor in earnings forecasting models.

\section{REFERENCES}

Abad, C., Banker, R.D. and Mashruwala, R. (2006) Eficiencia relativa como indicador del rendimiento futuro, Revista Iberoamericana de Contabilidad de Gestión (Iberoamerican Journal of Management Accounting), 8, 177-202.

Albretch, W.S., L. Lookabill and J. McKeown (1977) The time series properties of annual earnings, Journal of Accounting Research, 15, 226-44. 
Ball, R. and R. Watts (1972) Some time series properties of accounting income, Journal of Finance, 27, 663681.

Banker, R. D., Charnes A. and Cooper W.W. (1984) Some models for estimating technical and scale inefficiencies in Data Envelopment Analysis, Management Science, 30, 1078-92.

Banker, R. D. (1993) Maximum likelihood, consistency and data envelopment analysis: A statistical foundation, Management Science, 39(10), 1265-73.

Barnum D. T. and Gleason J. M. (2005) Technical efficiency bias caused by intra-input aggregation in data envelopment analysis, Applied Economics Letters, 12, 785-88.

Barnum D. T. and Gleason, J. M. (2006) Measuring efficiency in allocanting inputs among outputs with DEA, Applied Economics Letters, 13, 333-36.

Beaver, W. and D. Morse (1978) What determines price-earnings ratios?, Financial Analysts Journal, JulyAugust, 34, 65-76.

Brooks, L. and D.A. Buckmaster (1976) Further Evidence of the Time Series Properties of Accounting Income, The Journal of Finance, 31 (5), 1359-73.

Charnes, A., Cooper, W.W. and Rhodes, E. (1978) Measuring the Efficiency of Decision Making Units, European Journal of Operational Research, 2, 429-44.

Färe, R. and Zelenyuk, V. (2002) Input aggregation and technical efficiency, Applied Economics Letters, 9, 635-36.

Färe, R., Grosskopf, S. and Zelenyuk, V. (2004) Aggregation bias and its bounds in measuring technical efficiency, Applied Economics Letters, 11, 657-60.

Lee, C.M. (1999): Accounting-Based Valuation: Impact on Business Practices and Research, Accounting Horizons, 13 (4), 413-25.

Ohlson, J. (1995) Earnings, book values and dividends in security valuation, Contemporary Accounting Research,11(2), 661-87.

Reverte Maya, C. (2003) Evidencia empírica sobre la utilidad de la información financiera para la predicción de los resultados futuros, Revista Española de Financiación y Contabilidad (Spanish Journal of Accounting and Finance), Vol. 31 (111), 189-224.

Sengupta, J.K. (2002) Economics of efficiency measurement by the DEA approach, Applied Economics, 34, 1133-39.

Shroff, P. K. (1999) The variability of earnings and non-earnings information and earnings prediction", Journal of Business Finance \& Accounting, 26(7)\&(8), 863-82.

Watts, R. L. and R. Leftwich (1977) The time series of annual accounting earnings", Journal of Accounting Research, 15, 253-71.

White, H. (1980): "A heteroskedasticity-consistent covariance matrix estimator and a direct test for heteroskedasticity", Econometrica, 48, 817-38. 